\title{
Papillomavirus in cervicovaginal smears of women infected with Human Immunodefficiency Virus
}

\author{
Pathological Anatomy Session of the Instituto Emílio Ribas - Pathology Department of the \\ Faculdade de Medicina de São Paulo - Pathology Division of the Instituto Adolfo Lutz, São Paulo - SP, Brazil
}

\begin{abstract}
It has been described that women infected with the human immunodeffciency virus (HIV) present more frequent cytological abnormalities in cervicovaginal smears, generally related to infection by human papillomavirus (HPV). The present work is a study of cervicovaginal smears of $147 \mathrm{HIV}$-seropositive women submitted to routine gynecological examinations. The smears were stained by the Papanicolaou method. Cytopathic effects of HPV were found in $38(25.8 \%)$ cases. Nuclear atypias of cervical intraepithelial neoplasia (CIN) were evident in $36(24.5 \%)$ of these cases: $27(18.4 \%)$, CIN I; $6(4.0 \%)$, CIN II and $3(2.0 \%)$ CIN III. Also $2(1.4 \%)$ invasive carcinomas and one $(0.7 \%)$ endocervical dysplasia were found. Other agents observed were: Candida sp, $19(12.9 \%)$ cases, Gardnerella vaginalis, $19(12.9 \%)$, Trichomonas vaginalis, $13(8.4 \%)$, Chlamydia trachomatis 5 (3.4\%), Mobiluncus sp 2 $(1.4 \%)$ and Herpes simplex virus $1(0.7 \%)$. This study emphasizes the high frequency of HPV/CIN cervicovaginal abnormalities in HIV-seropositive in our population. It is possible that immunological factors and sexual promiscuity are involved in this phenomenon.
\end{abstract}

UNITERMS: HIV infection. Papillomavirus infection. Cervical intraepithelial neoplasia. Cervical neoplasia.

\section{INTRODUCTION}

$\mathrm{T}$ There has been a general consensus that genital human papillomaviruses (HPV) play a major causal role in the development of cervical intraepithelial neoplasia or cervical cancer $(2,9,11,12)$. HPV types and risk factors, especially immune state, may also play important roles (9). It has been described that the risk of developing neoplastic changes in the cervix is greater in immunosuppressed women than in the general population. Acquired Immunodefficiency Syndrome (AIDS) is a risk factor for pre-neoplastic/neoplastic cervicovaginal disorders as well for HPV infections, subclinical or symptomatic $(2,10)$. Squamous cell atypia and cytological signs of HPV infection were found in women seropositive for human immunodefficiency virus (HIV) at a significantly higher rate when compared to seronegative women (11). In the present work, we studied series of 147 cervicovaginal smears of HIV-seropositive women, submitted to routine gynecological examination. The smears were stained by the Papanicolaou method and analyzed to search for nuclear cytological abnormalities, HPV cytopathic effects and other agents.

\section{MATERIAL AND METHODS}

One hundred forty-seven outpatient women, seropositive for HIV, in different stages of the disease, 
were submitted to routine gynecological examinations. The mean age of the patients was 29.6 years (range 17 to 44 ) and the median 28.9 years. Samples of cervicovaginal smears were stained by the Papanicolaou method and analyzed by the Department of Pathology of the Instituto de Infectologia Emílio Ribas (São Paulo) in 1994, from January to December, to search for squamous and endocervical cell nuclear abnormalities, cytopathic effects of papillomavirus (HPV), and other agents. The cytological diagnosis was based on the WHO classification (7). We considered only classical criteria (kolilocytosis and dyskeratosis) for detection of HPV5.

\section{RESULTS}

Among 147 cases, cytopathic effects of HPV were observed in 38 (25.8\%) cases. Among these, 36 (24.5\%) showed abnormalities related to cervical intraepithelial neoplasia (CIN): $27(18.4 \%)$ CIN I, $6(4.0 \%)$ CIN II, and $3(2.0 \%)$ CIN III. Other two cases $(1.4 \%)$ showed invasive carcinoma and one, endocervical dysplasia. Other agents observed were: Candida sp, 19 cases (12.9\%), Gardnerella vaginalis, $19(12.9 \%)$, Trichomonas vaginalis, 13 (8.4\%), Chlamydia trachomatis, 5 (3.4\%), Mobiluncus sp, 2 (1.4\%) and Herpes simplex virus, $1(0.7 \%)$.

\section{DISCUSSION}

It has been described that women infected with HIV have genital HPV infections detected by southern blot, dot blot, and PCR more frequently than women without the HIV infection $(2,3,12)$. In the international medical literature, a higher rate of cervicovaginal abnormalities, such as cervical intraepithelial neoplasia (CIN) associated with HPV, have also been described in cervicovaginal smears (10).
In the present work, we studied a series of 147 Brazilian, HIV-infected women submitted to routine gynecological examinations. We found $38(25.8 \%)$ cases with cytopathic effects of HPV, 36 being clearly CIN cases (27 CIN I, 6 CIN II and 3 CIN III). We found also two cases of carcinoma, in which HPV cytopathic effects were not evident, perhaps because the lesions were advanced and only more sensitive techniques could detect HPV.

The frequency of HPV detection by cytology of cervicovaginal smears in the general population referred in reports of the international literature is near $2 \%(6,8)$. In the Health Public Service of São Paulo State, the frequency of HPV/CIN in women screened by cervicovaginal smears is similar. The Adolfo Lutz Institute screened 112,804 cervicovaginal smears (from 1990 to 1991 ) and found $1.5 \%$ of HPV/CIN-related cases (4). Considering the frequency of HPV/CIN detection by cervicovaginal cytology in general population, the higher frequency of these lesions in our series of HIV-infected women is unquestionable.

Schrager et al. (10), in 1989, and Vermund et al. (11), in 1991, found that the frequency of HPV infection and squamous intraepithelial lesions is greater in HIVseropositive women than in high risk HIV-seronegative women. Based on these data, it is possible to suppose that there are other factors besides sexual promiscuity involved in the greater frequency of HPV infection in HIV-infected women.

The mechanism of induction of HPV-mediated cervical pre-malignant lesions in HIV-infected women is unclear.

It is possible that immunodefficiency may favor the replication of HPV. In this context, Barton et al. (1) found a depletion of the Langerhans cells in the epithelial tissue of women with HIV.

A direct interaction between HIV and HPV at the cellular level, leading to transactivation, of viral replication has also been proposed (9).

Further studies may elucidate these mechanisms. Nevertheless, the present data strongly suggest that HIVinfected women have a higher risk of HPV infection associated or not with pre-neoplastic/neoplastic lesions of the cervix, and careful and frequent gynecological examinations must be recommended for this population. 


\section{RESUMO}

Introduçāo: Tem sido relatado que mulheres infectadas pelo HIV apresentam maior incidència de atipias citológicas nos estregaços cérvico-vaginais, relacionadas principalmente com a infecção pelo HPV. Material e Métodos: O presente trabalho representa o estudo de esfregaços cérvico-vaginais de 147 mulheres HIV-soropositivas, submetidas a exame ginecológico de rotina. Os esfregaços foram corados pelo método de Papanicolaou. Sinais citopáticos de infecção por HPV foram encontrados em $38(25,8 \%)$ casos. Resultados: Atipias nucleares de neoplasia intra-epitelial cervical foram evidentes em $36(24,5 \%)$ destes casos sendo 27 (18,4\%) grau I (NIC I), $6(4,0 \%)$ NIC II e $3(2,0 \%)$ NIC III. Observaram-se $2(1,4 \%)$ casos de carcinoma invasor e $1(0,7 \%)$ de displasia endocervical. Outros agentes encontrados foram: Cândida sp, 19 casos (12,9\%), Gardnerella vaginalis, $19(12,9 \%)$, Trichomonas vaginalis, $13(8,4 \%)$. Chlamydia trachomatis, $5(3,4 \%)$, Mobiluncus sp, $2(1,4 \%)$ e Herpes simplex virus, $1(0,7 \%)$. Conclusāo: Este estudo ressalta a alta incidēncia de HPV/NIC em pacientes HIV-positivas em nosso meio. É provável que fatores imunológicos e promiscuidade estejam envolvidos neste fenômeno.

\section{REFERENCES}

1. BARTON, S.; MADDOX, P.; SMITH, J.; JENKINS, D. \& HAWKINS, D. - A study of Langerhan's cells in the cervical epithelium of women with HIV infection. (Abstract 2130) In: Proceedings of the Sixth International Conference on AIDS, San Francisco, California, June 20-24, 1990. San Francisco: Sixth International Conference on AIDS: 379, 1990.

2. FEINGOLD, A.R.; VERMUND, S.H.; BURK, R.D.; KELLEY, K.F.; SCHRAGER, L.K.; SCHREIBER, K.; MUNK, G.; FRIEDLAND, G.H. \& KLEIN, R.S. - Cervical Cytologic abnormalities and Papillomavirus in women infected with human immunodefficiency virus. J Acq Immun Def Synd 3(9):896-903, 1990.

3. KUHLER-OBBARIUS, C.; MILDE-LANGOSH, K.; HELLING-GIESE, G.; SALFELDER, A.; PEIMANN, C. \& LONNING, T. - Polymerase chain reaction-assisted papillomavirus detection in cervicovaginal smears: stratification by clinical risk and cytology reports. Virchows Arch 425:157-163, 1994.

4. MAEDA, M.Y.S. \& CAVALIERE, M.J. - Novas perspectivas em citologia oncótica no Instituto Adolfo Lutz. Bol Inst Adolfo Lutz 2(1):6, 1992.

5. MEISELS, A.; ROY, M.; FORTIER, M. \& MORIN, C. Condylomatous lesions of the cervix: morphologic and colposcopic-diagnosis. Am J Diagn Gynecol Obstet 1:109116, 1979.
6. MEISELS, A.; ROY, M.; FORTIER, M.; MORIN, C.; CASAS-CORDERO, M.; SHAH, K.V. \& TURGEON, H. Human Papillomavirus infection of the cervix. The atypical condyloma. Acta Cytol 23(1):7-16, 1981.

7. Organización Mundial de la Salud. Manual de normas y procedimientos para el contról del cancer de cuello uterino. Washington, 1984, p.16.

8. SCHNEIDER, A.; KRAUS, H.; SCHHMANN, R. \& GISSMANN, L. - Papillomavirus infection of the lower genital tract: detection of viral DNA in gynecological swabs. Int J Cancer 35:443-448, 1985.

9. SCHNEIDER, A. - Pathogenesis of genital HPV infection. Genitourin Med 69:165-173, 1993.

10. SCHRAGER, L.K.; FRIEDLAND, G.H.; MAUDE, D.; SCHREIBER, K.; ADACHI, A.; RIZZUTTI, D.J.; KOSS, L.G. \& KLEIN, R.S. - Cervical and vaginal squamous cell abnormalities on women infected with human immunodeficiency virus. J Acq Immun Def Syn 2(6):570$575,1989$.

11. VERMUND, S.H.; KELLEY, K.F.; KLEIN, R.S.; FEINGOLD, A,R.; SCHREIBER, K.; MUNK, G. \& BURK, R.D. - High risk of human papillomavirus infection and cervical squamous intraepithelial lesions among women with symptomatic human immunodeficiency virus infection. Am J Obstet Gynecol 165(2):392-400, 1991.

12. WILLIAMS, A.B.; DARRAGH, T.M.; VRANIZAN, K.; OCHIVA, C.; MASS, A.R. \& PALEFSK, J.M. - Anal and cervical human papillomavirus infection and risk of anal and cervical epithelial abnormalities in human immnudeficiency virus infected women. Obst Gynecol 83(2):205-211, 1994. 